\title{
Dinuclear thiolato-bridged arene ruthenium complexes: from reaction conditions and mechanism to synthesis of new complexes
}

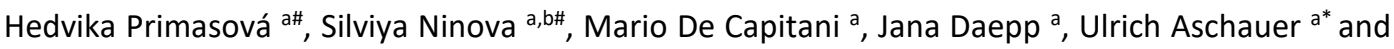
Julien Furrer ${ }^{\mathrm{a}^{*}}$

Several dinuclear thiophenolato-bridged arene ruthenium complexes $\left[\left(\eta^{6}-p-\mathrm{MeC}_{6} \mathrm{H}_{4} \mathrm{Pr}^{i}\right)_{2} \mathrm{Ru}_{2}\left(\mu_{2}-\mathrm{SC}_{6} \mathrm{H}_{4}-\mathrm{R}\right)_{3}\right]^{+}$could so far only be obtained with moderate yields using the synthetic route established in the early $2000 \mathrm{~s}$. With much less reactive aliphatic thiols or with bulky thiols, the reactions become even less efficient and the desired complexes are obtained with low yields or not at all. We employed density functional theory (DFT) calculations to gain a fundamental understanding of the reaction mechanisms leading to the formation of dithiolato and trithiolato complexes starting from the dichloro $(p$ cymene)ruthenium(II) dimer $\left[\left(\eta^{6}-p-\mathrm{MeC}_{6} \mathrm{H}_{4} \mathrm{Pr}^{i}\right) \mathrm{Ru}\left(\mu_{2}-\mathrm{Cl}\right) \mathrm{Cl}\right]_{2}$. The results of the DFT study enabled us to rationalise experimental results and allowed us, via a modified synthetic route, to synthesise previously unreported and hitherto considered as unrealistic complexes. Our study opens possibilities for the synthesis of so far inaccessible thiolato-bridged dinuclear arene ruthenium(II) complexes but more generally also the synthesis of other thiolato-bridged dinuclear group 8 and 9 metal complexes could be reexamined.
\end{abstract}

\section{Introduction}

Dinuclear tris(thiolato)-bridged arene complexes are typically obtained from the reaction of the precursor [(arene) $\mathrm{MCl}\left(\mu_{2^{-}}\right.$ $\mathrm{Cl})_{2} \mathrm{M}$ (arene) $\left.\mathrm{Cl}\right] \mathrm{M}=\mathrm{Fe}, \mathrm{Ru}, \mathrm{Rh}, \mathrm{Os}$, Ir with thiolate compounds and represent an interesting class of organometallic compounds. Iron complexes serve as carbon-halogen bond activation reagents, and carbon-halogen bond-cleavage agents, $^{1-4}$ while osmium ${ }^{5}$, iridium, rhodium ${ }^{6-12}$ and especially ruthenium complexes ${ }^{13,14,23-25,15-22}$ have in vitro antiproliferative activity against cancer cell lines and several protozoan parasites. Tris(thiolato)-bridged dimolybdenum complexes are also readily available but are synthesised using other strategies such as the direct oxidation of low-valence carbonyl precursors or reductive process from higher-valence derivatives, ${ }^{26-28}$ which will not be discussed here.

It is interesting to note that arene ruthenium(II) complexes were first obtained fortuitously about fifty years ago by Winkhaus and Singer and subsequently Zelonka and Baird. ${ }^{29-32}$ Only years later, these dimeric arene-ruthenium dichloride complexes $\left[\left(\eta^{6} \text {-arene }\right) \mathrm{Ru}\left(\mu_{2}-\mathrm{Cl}\right) \mathrm{Cl}\right]_{2}$ were found to react with thiols to give cationic trithiolato complexes of the type [ $\left(n^{6}-\right.$ arene $\left.)_{2} \mathrm{Ru}_{2}\left(\mu_{2}-\mathrm{SR}\right)_{3}\right]^{+}$, the first examples being the hexamethylbenzene derivative $\left[\left(\eta^{6}-\mathrm{C}_{6} \mathrm{Me}_{6}\right)_{2} \mathrm{Ru}_{2}\left(\mu_{2}-\mathrm{SPh}\right)_{3}\right]^{+}$ reported by Rakowski DuBois and coworkers ${ }^{33}$ and the $p$ cymene derivative $\left[\left(\eta^{6}-p-\mathrm{MeC}_{6} \mathrm{H}_{4} \mathrm{Pr}^{i}\right)_{2} \mathrm{Ru}_{2}\left(\mu_{2}-\mathrm{SPh}\right)_{3}\right]^{+}$reported by Nakamura and coworkers, both of which contain three thiophenolato bridges. ${ }^{34}$ Over the last fifteen years, the series of dinuclear trithiolato bridged arene ruthenium complexes was extended, including complexes of the general formula [ $\left(\eta^{6}-p\right.$ $\left.\left.\mathrm{MeC}_{6} \mathrm{H}_{4} \mathrm{Pr}^{i}\right)_{2} \mathrm{Ru}_{2}\left(\mu_{2}-\mathrm{SC}_{6} \mathrm{H}_{4}-\mathrm{R}\right)_{3}\right]^{+}$and so-called mixed complexes of the general formula $\left[\left(\eta^{6}-p-\mathrm{MeC}_{6} \mathrm{H}_{4} \mathrm{Pr}^{i}\right)_{2} \mathrm{Ru}_{2}\left(\mu_{2}-\mathrm{SC}_{6} \mathrm{H}_{4}-\mathrm{R}^{1}\right)_{2}\left(\mu_{2^{-}}\right.\right.$ $\left.\left.\mathrm{SC}_{6} \mathrm{H}_{4}-\mathrm{R}^{2}\right)\right]^{+}$, bearing two types of thiol ligands. ${ }^{13,14,36-39,15,18-20,22-}$ 24,35 Like many organometallic compounds, these dinuclear thiolato-bridged arene ruthenium complexes have originally been designed as catalysts, for instance for the carbonylation of methanol. ${ }^{40}$ While they did not attract much attention for this application, a revival started in 2008 , when water-soluble arene ruthenium complexes were discovered to be cytotoxic. ${ }^{14,40-44}$ Remarkably, almost all tested trithiolato compounds are highly cytotoxic with $\mathrm{IC}_{50}$ values being in the submicromolar range, the most potent ones with $\mathrm{IC}_{50}$ values of $30 \mathrm{nM}$ against $\mathrm{A} 2780$ cells and cisplatin-resistant A2780cisR cells. ${ }^{13,19,21,22}$ Recent in vivo studies have demonstrated that these complexes indeed have potential as anticancer drugs, since for instance the compound $\quad\left[\left(\eta^{6}-p-\mathrm{MeC}_{6} \mathrm{H}_{4} \mathrm{Pr}^{i}\right)_{2} \mathrm{Ru}_{2}\left(\mu_{2}-\mathrm{S}-p-\mathrm{C}_{6} \mathrm{H}_{4} \mathrm{Bu}^{t}\right)_{3}\right] \mathrm{Cl}$ (termed diruthenium-1) significantly prolongs the survival of tumour-bearing mice ${ }^{25}$ and substantially influences metabolism of A2780cisR cells involving changes related to redox homeostasis, Warburg effect and lipid metabolism. ${ }^{45}$ Other derivatives appear less promising.44,46 Dinuclear thiolatobridged arene ruthenium complexes are also promising as antiprotozoal agents, with $\mathrm{IC}_{50}$ values of up to $1.2 \mathrm{nM}$ against T. gondii, N. Caninum and T. Brucei and $\mathrm{IC}_{50}$ values against human foreskin fibroblasts $>800 \mu \mathrm{M}$, leading to selectivity indexes $>20^{\prime} 000 .^{16,17,47}$

The current synthesis route for obtaining dinuclear cationic trithiolato bridged arene ruthenium complexes of the general formula $\left[\left(\eta^{6}-p-\mathrm{MeC}_{6} \mathrm{H}_{4} \mathrm{Pr}^{i}\right)_{2} \mathrm{Ru}_{2}\left(\mu_{2}-\mathrm{S}-\mathrm{R}\right)_{3}\right]^{+}$with good yields dates back to the early 2000s and involves the reaction of the dimer $\left[\left(\eta^{6}-p-\mathrm{MeC}_{6} \mathrm{H}_{4} \mathrm{Pr}^{i}\right) \mathrm{Ru}\left(\mu_{2}-\mathrm{Cl}\right) \mathrm{Cl}_{2}\right.$ with an excess of the corresponding thiol (see Scheme 1 ) usually in refluxing ethanol (EtOH). ${ }^{37}$ For thiophenolato complexes, depending on the thiophenol used, it is possible to adjust the conditions to direct the synthesis exclusively to the cationic trithiophenolato complex $\left[\left(\eta^{6}-p-\mathrm{MeC}_{6} \mathrm{H}_{4} \mathrm{Pr}^{i}\right)_{2} \mathrm{Ru}_{2}\left(\mu_{2}-\mathrm{SC}_{6} \mathrm{H}_{4}-\mathrm{R}\right)_{3}\right]^{+},{ }^{15}$ the neutral dithiophenolato complex $\left[\left(\eta^{6}-p-\mathrm{MeC}_{6} \mathrm{H}_{4} \mathrm{Pr}^{i}\right)_{2} \mathrm{Ru}_{2}\left(\mu_{2}-\mathrm{SC}_{6} \mathrm{H}_{4}-\right.\right.$ $\left.\mathrm{R}_{2} \mathrm{Cl}_{2}\right],{ }^{48}$ or even the neutral monothiophenolato complex $\left[\left(\eta^{6}-\right.\right.$ $\left.\left.p-\mathrm{MeC}_{6} \mathrm{H}_{4} \mathrm{Pr}^{i}\right)_{2} \mathrm{Ru}_{2} \mathrm{Cl}_{2}(\mu-\mathrm{Cl})\left(\mu_{2}-\mathrm{SC}_{6} \mathrm{H}_{4}-\mathrm{R}\right)\right] .{ }^{49}$ The reactivity of the thiol undoubtedly plays an important role and decides to a great extent the outcome of the reaction. For instance, the trithiophenolato complexes $\left[\left(\eta^{6}-p-\mathrm{MeC}_{6} \mathrm{H}_{4} \mathrm{Pr}^{i}\right)_{2} \mathrm{Ru}_{2}\left(\mu_{2^{-}}\right.\right.$ $\left.\left.\mathrm{SC}_{6} \mathrm{H}_{4}-\mathrm{R}\right)_{3}\right]^{+}$with the electron attracting substituents $\mathrm{R}=\mathrm{NO}_{2}$ or $R=F$ could so far be only obtained with moderate yields ( 48 and 
$45 \%$, respectively) using the standard strategy described in Scheme $1 .{ }^{19}$ Similarly, when much less reactive aliphatic thiols are used, the reaction becomes more demanding and the desired trithiolato complexes are either obtained with modest yields or the reactions only give the neutral dithiolato complex. For instance, the trithiolato complex $\left[\left(n^{6}-p\right.\right.$ $\left.\left.\mathrm{MeC}_{6} \mathrm{H}_{4} \mathrm{Pr}^{i}\right)_{2} \mathrm{Ru}_{2}\left(\mu_{2}-\mathrm{SC}_{8} \mathrm{H}_{17}\right)_{3}\right]^{+}$was only obtained with a yield of $28 \%$, despite a long 7 day reaction in $\mathrm{EtOH}$ under inert atmosphere and reflux conditions, ${ }^{50}$ and the trithiolato complex $\left[\left(\eta^{6}-p-\mathrm{MeC}_{6} \mathrm{H}_{4} \mathrm{Pr}^{i}\right)_{2} \mathrm{Ru}_{2}\left(\mu_{2}-\mathrm{SC}_{6} \mathrm{H}_{11}\right)_{3}\right]^{+}$could not be obtained from the neutral dithiolato complex $\left[\left(\eta^{6}-p-\mathrm{MeC}_{6} \mathrm{H}_{4} \mathrm{Pr}^{i}\right)_{2} \mathrm{Ru}_{2}\left(\mu_{2^{-}}\right.\right.$ $\left.\mathrm{SC}_{6} \mathrm{H}_{11}\right)_{2} \mathrm{Cl}_{2}$ ], presumably due to steric reasons. ${ }^{48}$
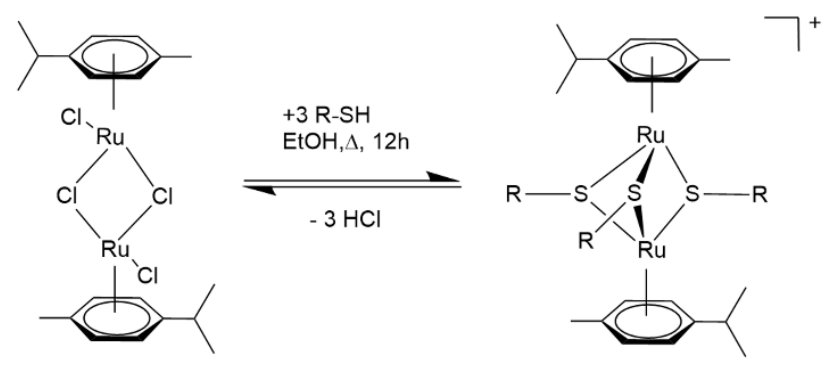

Scheme 1. Synthesis of dinuclear cationic trithiolato-bridged arene ruthenium complexes. ${ }^{37}$

These experimental facts raise the question as to whether the formation of dinuclear trithiolato-bridged arene ruthenium complexes with different thiols is thermodynamically or kinetically hindered, which would give indications as to how conditions should be altered to enable reactions or to improve yields.

In the present work we aim at a fundamental understanding of the reaction mechanisms leading to the formation of trithiolato complexes starting from the dichloro( $p$-cymene)ruthenium(II) dimer $\left[\left(\eta^{6}-p-\mathrm{MeC}_{6} \mathrm{H}_{4} \mathrm{Pr} i\right) \mathrm{Ru}\left(\mu_{2}-\mathrm{Cl}\right) \mathrm{Cl}\right]_{2}$ and to modify, where necessary, the existing synthetic route to (i) increase the yields, (ii) reduce the overall reaction time (currently reflux in $\mathrm{EtOH}$, $18 \mathrm{~h}$ ), and to (iii) synthesise novel thiolato bridged complexes.

To this end, we employ density functional theory (DFT) calculations of the possible synthetic routes for trithiolato complexes $\left[\left(\eta^{6}-p-\mathrm{MeC}_{6} \mathrm{H}_{4} \mathrm{Pr}^{i}\right)_{2} \mathrm{Ru}_{2}\left(\mu_{2}-\mathrm{SR}\right)_{3}\right]^{+}$. The DFT results agree with new experimental results obtained for the trithiophenolato complexes $\quad\left[\left(\eta^{6}-p-\mathrm{MeC}_{6} \mathrm{H}_{4} \mathrm{Pr}^{i}\right)_{2} \mathrm{Ru}_{2}\left(\mu_{2^{-}}\right.\right.$ $\left.\left.\mathrm{SC}_{6} \mathrm{H}_{4}-\mathrm{R}\right)_{3}\right]^{+}$with $\mathrm{R}=\mathrm{H}(\mathbf{1}), \mathrm{R}=\mathrm{p}-\mathrm{OMe}(\mathbf{2})$, and $\mathrm{R}=\mathrm{p}-\mathrm{NO}_{2}(\mathbf{3})$, and the previously unreported trithiolato complexes $\left[\left(\eta^{6}-p\right.\right.$ $\left.\left.\mathrm{MeC}_{6} \mathrm{H}_{4} \mathrm{Pr}^{i}\right)_{2} \mathrm{Ru}_{2}\left(\mu_{2}-\mathrm{SC}_{6} \mathrm{H}_{11}\right)_{3}\right]^{+}(4)$ and (5). Applying this approach further, we improved yield for (6) and were also able to synthesise two new dithiophenolato complexes (7) and (8) (Figure 1), previously considered inaccessible, since only dithiobenzylato complexes could be obtained so far. ${ }^{18,46,48}$

\section{Computational methods}

All calculations were carried out with the $\mathrm{CP} 2 \mathrm{~K}$ package ${ }^{51}$ within the mixed Gaussian and Plane-Wave DFT formalism. ${ }^{52,53}$ The core-region of wave functions was smoothed out with norm-conserving dual-space Goedecker-Teter-Hutter pseudopotentials ${ }^{54,55}$, whereas the valence pseudo-wave functions were expanded in molecularly optimised double-zeta valence polarised (DZVP) Gaussian basis sets for all elements. ${ }^{56}$ The auxiliary plane-wave basis set, used to calculate the Hartree potential, had a cut-off of 750 Ry. The BLYP functional was used $^{57,58}$ with Grimme's D3 dispersion correction ${ }^{59}$ and BeckeJohnson (BJ) for the DFT-D3 damping function, which was reported to reduce the error for reaction barriers in BLYP calculations. ${ }^{60}$ Hybrid functionals, such as B3LYP, B3PW91 and $\mathrm{PBEO}$, have been previously used to computationally investigate Ru-complexes. ${ }^{61-64}$ Due to the small geometry, energy and occupied electronic-structure differences between PBEO, B3LYP and BLYP, reported in the SI (see Table S7) and combined with the higher computational cost of hybrid-functional calculations in particular for barriers, we opt to carry out all calculations with BLYP. The wave function optimization was carried out with the orbital transformation method, ${ }^{65}$ while the geometry of complexes was relaxed until forces converged below $0.02 \mathrm{eV} / \AA$ and the energy difference between subsequent self-consistent steps was less than $10^{-6} \mathrm{Ha}$. Calculations were carried out in periodic simulation boxes of dimensions $30 \times 30 \times 30 \AA$ that limit spurious interactions due to a distance of about $15 \AA$ between periodic images of the complexes. The $\mathrm{Ru}(\mathrm{II})$ ion is considered to be non-magnetic as a geometry optimised ferromagnetic complex with spin multiplicity 9 lies $1.6 \mathrm{eV}$ higher in energy. With this computational protocol, the average geometry deviation was determined to be about $0.81 \%$ with respect to experiment (see Table S7 in SI).

All reaction mechanisms and their corresponding barriers were determined with the climbing image variant of the Nudged Elastic Band method. ${ }^{66}$ Each path was minimised until the energy difference converged below $0.002 \mathrm{eV}$.

The self-consistent continuum solvation model, SCCS, ${ }^{67}$ was used to implicitly account for the presence of a solvent. The cavity was defined as regions in the simulation cells with an electron density higher than $10^{-4} \mathrm{e} / \mathrm{Bohr}^{3}$, while the continuum region is defined for densities smaller than $10^{-5} \mathrm{e} / \mathrm{Bohr}^{3}$. The dielectric constants for dichloromethane and ethanol were set to 8.93 and 24.55 , respectively. No further geometry relaxation was performed for structures in implicit solvent. 68

\section{Experimental section}

The dichloro( $p$-cymene)ruthenium(II) dimer $\left[\left(n_{6}-p\right.\right.$ $\left.\left.\mathrm{MeC}_{6} \mathrm{H}_{4} \mathrm{Pr}^{i}\right) \mathrm{Ru}\left(\mu_{2}-\mathrm{Cl}\right) \mathrm{Cl}\right]_{2}$, $p$-nitrothiophenol (technical grade), cyclohexylthiol, thiophenol and N,N-Diisopropylethylamine (DIPEA) were purchased from Sigma Aldrich. $p$ methoxythiophenol was bought from Alfa Aesar. $\mathrm{CDCl}_{3}$ and MeOD were obtained from Cambridge Isotope Laboratories, $\mathrm{CD}_{2} \mathrm{Cl}_{2}$ was obtained from Eurisotop. All reactions were performed under inert atmosphere using standard Schlenk technique. NMR spectra were recorded on Bruker spectrometers: AVANCE III HD $300 \mathrm{MHz}$ equipped with a $5 \mathrm{~mm}$ ATM BBFO probehead, AVANCE III HD $400 \mathrm{MHz}$ equipped with a $5 \mathrm{~mm}$ ATM BBFO SmartProbe probehead, AVANCE II $400 \mathrm{MHz}$ 
equipped with a $5 \mathrm{~mm}$ ATM Dual probehead and AVANCE II 500 $\mathrm{MHz}$ equipped with a $1.7 \mathrm{~mm}$ TXI ${ }^{1} \mathrm{H}$ probehead, respectively. Unless specified otherwise NMR spectra were recorded at room temperature $\left(25^{\circ} \mathrm{C}\right)$ and processed using Topspin software (Bruker Biospin). MS and elemental analysis were performed, a LTQ Orbitrap XL with nano ESI (Thermo). All syntheses and purifications employing column chromatography are described in more detail in the SI.

\subsection{Synthesis of 1}

$\left[\left(\eta^{6}-p-\mathrm{MeC}_{6} \mathrm{H}_{4} \mathrm{Pr}^{i}\right)_{2} \mathrm{Ru}_{2}\left(\mu_{2}-\mathrm{SC}_{6} \mathrm{H}_{5}\right)_{3}\right] \mathrm{Cl}$ (1) was obtained from the reaction of the dichloro( $p$-cymene)ruthenium(II) dimer [ $\left(\eta_{6}-p\right.$ $\left.\left.\mathrm{MeC}_{6} \mathrm{H}_{4} \mathrm{Pr}^{i}\right) \mathrm{Ru}\left(\mu_{2}-\mathrm{Cl}\right) \mathrm{Cl}\right]_{2}$ with thiophenol. ${ }^{34}$ Four different reaction conditions were evaluated: (i) in DCM, 1 was obtained with $62 \%$ yield in $7 \mathrm{~h}$, (ii) in DCM with addition of DIPEA, with $79 \%$ yield in $3 \mathrm{~h}$, (iii) in $\mathrm{EtOH}$ with $69 \%$ yield in $23 \mathrm{~h}$ and (iv) in $\mathrm{EtOH}$ with addition of DIPEA with $80 \%$ yield in $3 \mathrm{~h}$. Reactions in $\mathrm{EtOH}$ were performed under reflux at $78-83^{\circ} \mathrm{C}$ while reactions in DCM were performed at $40-45^{\circ} \mathrm{C}$. The analytical data are provided in the SI (Figures S9-11) and are in agreement with the literature. ${ }^{34}$

\subsection{Synthesis of 2}

$\left[\left(\eta^{6}-p-\mathrm{MeC}_{6} \mathrm{H}_{4} \mathrm{Pr}^{i}\right)_{2} \mathrm{Ru}_{2}\left(\mu_{2}-\mathrm{SC}_{6} \mathrm{H}_{4}-\mathrm{OMe}\right)_{3}\right] \mathrm{Cl}$ (2) was obtained in $73 \%$ yield from the reaction of $\left[\left(\eta^{6}-p-\mathrm{MeC}_{6} \mathrm{H}_{4} \mathrm{Pr}\right) \mathrm{Ru}\left(\mu_{2}-\mathrm{Cl}\right) \mathrm{Cl}\right]_{2}$ with $p$-methoxythiophenol in DCM under reflux at $38-45^{\circ} \mathrm{C}$ under $\mathrm{N}_{2}$ atmosphere in $9 \mathrm{~h}$. The analytical data are provided in the SI (Figures S12-14) and are in agreement with the literature. ${ }^{19}$

\subsection{Synthesis of 3}

$\left[\left(\eta^{6}-p-\mathrm{MeC}_{6} \mathrm{H}_{4} \mathrm{Pr}^{i}\right)_{2} \mathrm{Ru}_{2}\left(\mu_{2}-\mathrm{SC}_{6} \mathrm{H}_{4}-\mathrm{NO}_{2}\right)_{3}\right] \mathrm{Cl}$ (3) was obtained in $73 \%$ yield from the reaction of $\left[\left(\eta^{6}-p-\mathrm{MeC}_{6} \mathrm{H}_{4} \mathrm{Pr}^{i}\right) \mathrm{Ru}\left(\mu_{2}-\mathrm{Cl}\right) \mathrm{Cl}\right]_{2}$ with $p$-nitrothiophenol in DCM under reflux at $40-45^{\circ} \mathrm{C}$ under $\mathrm{N}_{2}$ atmosphere in $2 \mathrm{~h}$. The analytical data are provided in $\mathrm{SI}$ (Figures S15-17) and are in agreement with the literature. ${ }^{19}$

\subsection{Synthesis of 4}

$\left[\left(\eta^{6}-p-\mathrm{MeC}_{6} \mathrm{H}_{4} \mathrm{Pr}^{i}\right)_{2} \mathrm{Ru}_{2}\left(\mu_{2}-\mathrm{SC}_{6} \mathrm{H}_{11}\right)_{3}\right] \mathrm{Cl}(4)$ was obtained from an 7 day reaction of $\left[\left(\eta^{6}-p-\mathrm{MeC}_{6} \mathrm{H}_{4} \mathrm{Pr}^{i}\right) \mathrm{Ru}\left(\mu_{2}-\mathrm{Cl}\right) \mathrm{Cl}\right]_{2}$ with cyclohexanethiol in DCM with addition of DIPEA under reflux at 40-45 ${ }^{\circ} \mathrm{C}$ under $\mathrm{Ar}$ atmosphere taking. Despite of our efforts, the desired complex 4 could not be obtained in pure form, because an inseparable mixture trithiolato/dithiolato was obtained. Analytical data (Figures S18-21): ${ }^{1} \mathrm{H} \mathrm{NMR}(400.1 \mathrm{MHz}$, $\left.\mathrm{CDCl}_{3}\right): \delta_{\mathrm{H}}=5.48(\mathrm{~m}, 4 \mathrm{H} ; \mathrm{H}$-Ar $p$-cymene), $5.35(\mathrm{~m}, 2 \mathrm{H} ; \mathrm{H}-\mathrm{Ar} p$ cymene), 5.29 (d, $J_{H, H}=5.0 \mathrm{~Hz}, 2 \mathrm{H} ; \mathrm{H}$-Ar p-cymene), 2.57 (sept, $\left.J_{H, H}=6.7 \mathrm{~Hz}, 2 \mathrm{H} ; \underline{\mathrm{C}}\left(\mathrm{CH}_{3}\right)_{2}\right), 2.37(\mathrm{~m}, 6 \mathrm{H} ; \mathrm{H} 1$ thiol), $2.21(\mathrm{~s}, 6 \mathrm{H}$; $\left.\mathrm{CH}_{3}\right), 1.73(\mathrm{~m}, 6 \mathrm{H}$; thiol), $1.51(\mathrm{~m}, 6 \mathrm{H}$; thiol), $1.39(\mathrm{~m}, 6 \mathrm{H}$; thiol), $1.31\left(\mathrm{~d}, J_{H, H}=6.7 \mathrm{~Hz}, 6 \mathrm{H} ; \mathrm{CH}\left(\mathrm{CH}_{3}\right)_{2}\right), 1.26\left(\mathrm{~d}, J_{H, H}=6.7 \mathrm{~Hz}, 6 \mathrm{H}\right.$; $\left.\mathrm{CH}\left(\mathrm{CH}_{3}\right)_{2}\right), 0.96 \mathrm{ppm}\left(\mathrm{m}, 9 \mathrm{H}\right.$; thiol); $\left.{ }^{13} \mathrm{C} \mathrm{NMR} \mathrm{(100} \mathrm{MHz;} \mathrm{CDCl}_{3}\right)$ : $\delta_{\mathrm{C}}=106.5$ (C1 p-cymene), 101.4 (C4 p-cymene), 83.7 ( $\mathrm{Ar} \mathrm{CH} \mathrm{p-}$ cymene), 83.2 (Ar CH p-cymene), 83.1 (Ar CH p-cymene), 82.9 (Ar CH p-cymene), 39.0 (thiol), 32.8 (thiol), $31.6\left(\mathrm{CH}\left(\mathrm{CH}_{3}\right)_{2}+\right.$ thiol), 28.9 (thiol), $24.0\left(\mathrm{CH}\left(\mathrm{CH}_{3}\right)_{2}\right), 22.6$ (thiol), $22.4\left(\mathrm{CH}\left(\mathrm{CH}_{3}\right)_{2}\right)$, $18.3\left(\mathrm{CH}_{3}\right), 14.1 \mathrm{ppm}$ (thiol); ESI-MS (positive mode, $\mathrm{MeOH}$ ): $\mathrm{m} / \mathrm{z}=817.2 ; \mathrm{Mw}=851.67 \mathrm{~g} / \mathrm{mol}$.

\subsection{Synthesis of 5}

$\left[\left(\eta^{6}-p-\mathrm{MeC}_{6} \mathrm{H}_{4} \mathrm{Pr}^{i}\right)_{2} \mathrm{Ru}_{2}\left(\mu_{2}-\mathrm{SC}_{6} \mathrm{H}_{13}\right)_{3}\right] \mathrm{Cl}(5)$ was obtained from the reaction $\left[\left(\eta^{6}-p-\mathrm{MeC}_{6} \mathrm{H}_{4} \mathrm{Pr}^{i}\right) \mathrm{Ru}\left(\mu_{2}-\mathrm{Cl}\right) \mathrm{Cl}\right]_{2}$ and 1-hexanethiol in DCM under reflux at $40-45^{\circ} \mathrm{C}$ with addition of DIPEA and $\mathrm{Ar}$ atmosphere in $68 \mathrm{~h}$. An analogous reaction was performed in ethanol for comparison. The reaction in DCM gave the product in $62 \%$ yield, in $\mathrm{EtOH}$ in $42 \%$ yield. Analytical data (Figures $\mathrm{S} 22-$ 24): ${ }^{1} \mathrm{H}$ NMR (300.1 MHz, $\left.\mathrm{CDCl}_{3}\right): \delta_{\mathrm{H}}=5.47(\mathrm{~m}, 4 \mathrm{H} ; \mathrm{H}-\mathrm{Ar} p-$ cymene), 5.34 (d, $J_{H, H}=5.7 \mathrm{~Hz}, 2 \mathrm{H} ; \mathrm{H}$-Ar $p$-cymene), 5.28 (d, $J_{H, H}$ $=5.7 \mathrm{~Hz}, 2 \mathrm{H} ; \mathrm{H}$-Ar p-cymene), 2.56 (sept, $J_{H, H}=7.0 \mathrm{~Hz}, 2 \mathrm{H}$; $\left.\mathrm{C} \underline{\mathrm{H}}\left(\mathrm{CH}_{3}\right)_{2}\right), 2.36\left(\mathrm{~m}, 6 \mathrm{H} ; \mathrm{SCH}_{2}\right), 2.19\left(\mathrm{~s}, 6 \mathrm{H} ; \mathrm{CH}_{3} p\right.$-cymene), 1.73 $\left(\mathrm{m}, 6 \mathrm{H} ; \mathrm{CH}_{2}\right), 1.50\left(\mathrm{p}, \mathrm{J}_{\mathrm{H}, \mathrm{H}}=7.5 \mathrm{~Hz}, 6 \mathrm{H} ; \mathrm{CH}_{2}\right), 1.37\left(\mathrm{~m}, 12 \mathrm{H}, \mathrm{CH}_{2}\right)$, $1.29\left(\mathrm{~d}, J_{H, H}=7.0 \mathrm{~Hz}, 6 \mathrm{H} ; \mathrm{CH}\left(\mathrm{CH}_{3}\right)_{2}\right), 1.17\left(\mathrm{~d}, J_{H, H}=7.0 \mathrm{~Hz}, 6 \mathrm{H}\right.$; $\left.\mathrm{CH}\left(\mathrm{CH}_{3}\right)_{2}\right), 0.95 \mathrm{ppm}\left(\mathrm{t}, \mathrm{J}_{\mathrm{H}, \mathrm{H}}=6.8 \mathrm{~Hz}, 9 \mathrm{H} ; \mathrm{CH}_{3}\right.$ thiol); ${ }^{13} \mathrm{C} \mathrm{NMR}$ $\left(100 \mathrm{MHz}, \mathrm{CDCl}_{3}\right): \delta_{\mathrm{C}}=106.5$ (Cq $p$-cymene), 101.4 (Cq $p$ cymene), 83.7 (Ar CH p-cymene), 83.2 (Ar CH p-cymene), 83.1 (Ar $\mathrm{CH}$ p-cymene), 82.9 ( $\mathrm{Ar} \mathrm{CH}$ p-cymene), $39.1\left(\mathrm{SCH}_{2}\right), 32.9$ $\left(\mathrm{CH}_{2}\right), 31.7$ and $31.6\left(\underline{\mathrm{C}} \mathrm{H}\left(\mathrm{CH}_{3}\right)_{2}\right.$ and $\left.\mathrm{CH}_{2}\right), 29.7,28.9\left(\mathrm{CH}_{2}\right), 24.0$ $\left(\mathrm{CH}\left(\mathrm{CH}_{3}\right)_{2}\right), 22.6\left(\mathrm{CH}\left(\underline{C}_{3}\right)_{2}\right), 22.5\left(\mathrm{CH}_{2}\right), 18.3\left(\mathrm{CH}_{3} p\right.$-cymene $)$, $14.1\left(\mathrm{CH}_{3}\right.$ thiol). ESI-MS (positive mode, EtOH): $\mathrm{m} / \mathrm{z}=823.2$; elemental analysis calcd (\%) for $\mathrm{C}_{38} \mathrm{H}_{67} \mathrm{Ru}_{2} \mathrm{~S}_{3} \mathrm{Cl} \cdot 1 / 2 \mathrm{H}_{2} \mathrm{O}: \mathrm{C} 52.66, \mathrm{H}$ 7.91; Found: C 52.57, H 7.95; $\mathrm{Mw}=866.73 \mathrm{~g} / \mathrm{mol}$.

\subsection{Synthesis of 6}

$\left[\left(\eta^{6}-p-\mathrm{MeC}_{6} \mathrm{H}_{4} \mathrm{Pr}^{i}\right)_{2} \mathrm{Ru}_{2}\left(\mu_{2}-\mathrm{SC}_{6} \mathrm{H}_{4}-\mathrm{F}\right)_{3}\right] \mathrm{Cl}(6)$ was obtained in $80 \%$ yield from the reaction of $\left[\left(\eta^{6}-p-\mathrm{MeC}_{6} \mathrm{H}_{4} \mathrm{Pr} i\right) \mathrm{Ru}\left(\mu_{2}-\mathrm{Cl}\right) \mathrm{Cl}\right]_{2}$ and $p$ fluorothiophenol in DCM under Ar atmosphere and reflux at 40$45^{\circ} \mathrm{C}$ with addition of DIPEA in $3.5 \mathrm{~h}$. The analytical data are described in SI (Figures S25-27) and are in agreement with the literature. ${ }^{19}$

\subsection{Synthesis of 7}

$\left[\left(\eta^{6}-p-\mathrm{MeC}_{6} \mathrm{H}_{4} \mathrm{Pr}^{i}\right)_{2} \mathrm{Ru}_{2}\left(\mu_{2}-\mathrm{SC}_{6} \mathrm{H}_{4}-p-\mathrm{Bu}^{t}\right)_{2} \mathrm{Cl}_{2}\right]$ (7) was obtained in quantitative yield from the reaction of $\left[\left(\eta^{6}-p-\mathrm{MeC}_{6} \mathrm{H}_{4} \mathrm{Pr}\right) \mathrm{Ru}\left(\mu_{2^{-}}\right.\right.$ $\mathrm{Cl}) \mathrm{Cl}_{2}$ and $p$-t-butylthiophenol in DCM cooled to $0{ }^{\circ} \mathrm{C}$ in $3.5 \mathrm{~h}$. Analytical data (Figures S28-30): ${ }^{1} \mathrm{H} \mathrm{NMR}\left(300.1 \mathrm{MHz}, \mathrm{CDCl}_{3}\right.$ ): $\delta_{\mathrm{H}}=7.89$ and $7.54\left(\mathrm{br}, 4 \mathrm{H}\right.$; H-Ar thiol), $7.34\left(\mathrm{~d}, J_{H, H}=7.7 \mathrm{~Hz}, 4 \mathrm{H}\right.$; $\mathrm{H}$-Ar thiol), 5.28, 5.18 and 5.04 (br, 8H; H-Ar p-cymene), 2.21 (br, $\left.2 \mathrm{H} ; \mathrm{C} \underline{\mathrm{H}}\left(\mathrm{CH}_{3}\right)_{2}\right), 1.90$ and $1.74\left(\mathrm{br}, 6 \mathrm{H}, \mathrm{CH}_{3} p\right.$-cymene), 1.30 (br, $\left.18 \mathrm{H} ; \mathrm{C}\left(\mathrm{CH}_{3}\right)_{3}\right), 0.99$ and $0.91 \mathrm{ppm}\left(\mathrm{br}, 12 \mathrm{H} ; \mathrm{CH}\left(\mathrm{CH}_{3}\right)_{2}\right) ;{ }^{13} \mathrm{C}$ $\operatorname{NMR}\left(100 \mathrm{MHz}, \mathrm{CDCl}_{3}\right): \delta_{\mathrm{C}}=152.3\left(\underline{\mathrm{C}}\left(\mathrm{CH}_{3}\right)_{3}\right), 136.7$ (Ar Cq thiol), 131.8 ( $\mathrm{CH}$ thiol), 126.4 ( $\mathrm{CH}$ thiol), 83.6 - 83.3 ( $\mathrm{Ar} \mathrm{CH}$ p-cymene), 34.9, $31.2\left(\mathrm{C}\left(\underline{\mathrm{CH}}_{3}\right)_{3}\right), 30.6\left(\underline{\mathrm{C}} \mathrm{H}\left(\mathrm{CH}_{3}\right)_{2}\right), 22.1\left(\mathrm{CH}\left(\underline{\mathrm{C}} \mathrm{H}_{3}\right)_{2}\right), 17.9(p-$ cymene $\mathrm{CH}_{3}$ ); ESI-MS (positive mode, EtOH): $\mathrm{m} / \mathrm{z}$ 837.1; elemental analysis calcd (\%) for $\mathrm{C}_{40} \mathrm{H}_{54} \mathrm{~S}_{2} \mathrm{Ru}_{2} \mathrm{Cl}_{2} \cdot 1 / 2 \mathrm{CH}_{2} \mathrm{Cl}_{2}$ : C 53.19, H 6.06; found: C 53.24, H 6.05; $\mathrm{Mw}=914.50 \mathrm{~g} / \mathrm{mol}$. 


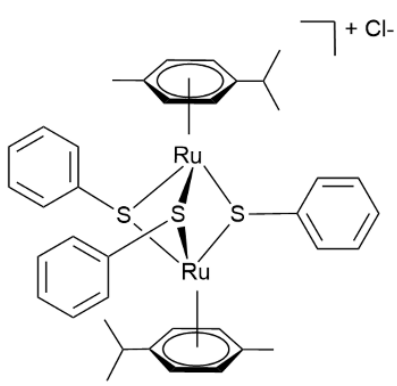

1

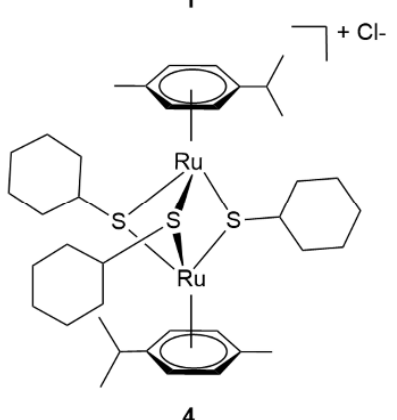

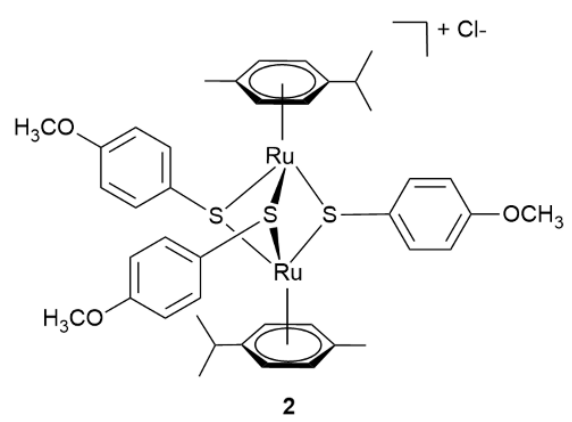

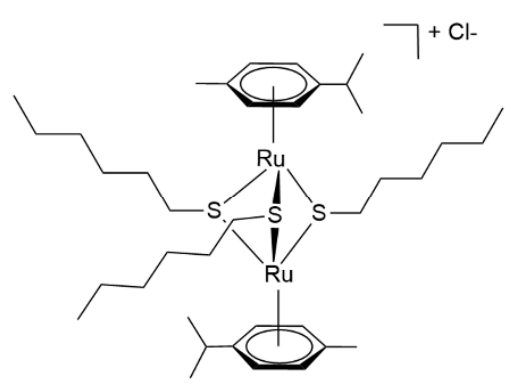

5

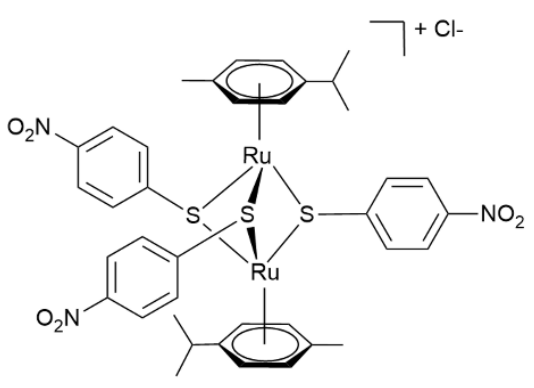

3

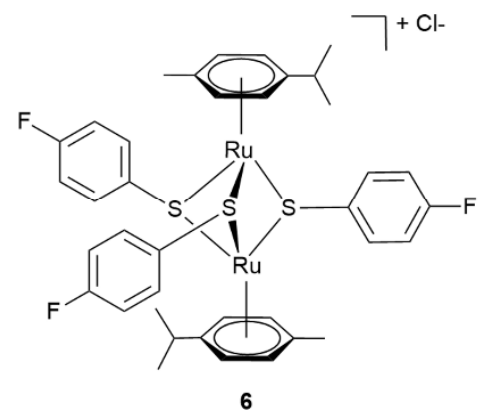

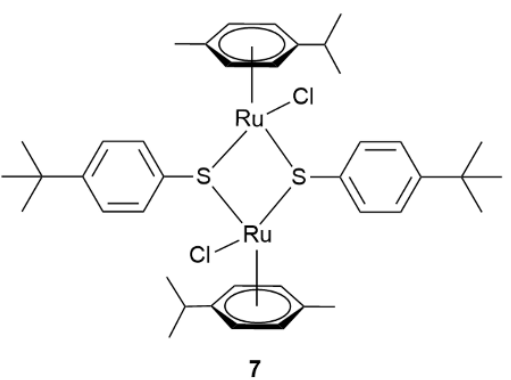

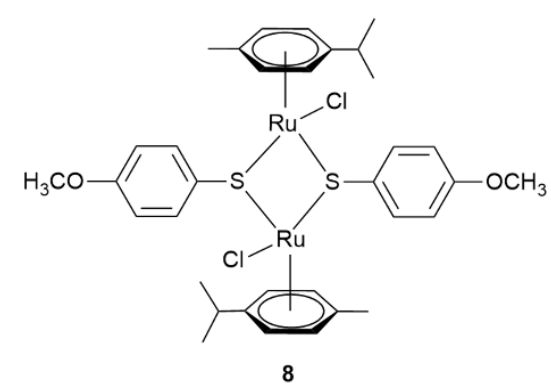

Figure 1. Structures of the six dinuclear trithiolato-bridged (1-6) and the two dinuclear dithiolato-bridged arene ruthenium complexes (7-8) investigated and synthesised.

\subsection{Synthesis of 8}

$\left[\left(\eta^{6}-p-\mathrm{MeC}_{6} \mathrm{H}_{4} \mathrm{Pr}^{i}\right)_{2} \mathrm{Ru}_{2}\left(\mu_{2}-\mathrm{SC}_{6} \mathrm{H}_{4}-p-\mathrm{Bu}^{t}\right)_{2} \mathrm{Cl}_{2}\right]$ obtained from the reaction of $\left[\left(\eta^{6}-p-\mathrm{MeC}_{6} \mathrm{H}_{4} \mathrm{Pr}^{i}\right) \mathrm{Ru}\left(\mu_{2^{-}}\right.\right.$ $\mathrm{Cl}) \mathrm{Cl}]_{2}$ and $p$-methoxythiophenol in DCM stirred at room temperature for $4 \mathrm{~h}$, but not in high purity. Analytical data (Figure S31-33): ${ }^{1} \mathrm{H}$ NMR (400.1 MHz, $\left.\mathrm{CDCl}_{3}\right): \delta_{\mathrm{H}}=7.93$ and 7.56 (br, $4 \mathrm{H} ; \mathrm{H}-$ Ar thiol), 6.87 (d, $J_{H, H}=8.4 \mathrm{~Hz}, 4 \mathrm{H} ; \mathrm{H}-$ Ar thiol), 5.18 and $5.00\left(\mathrm{br}, 8 \mathrm{H}\right.$; $\mathrm{H}$-Ar p-cymene), $3.82\left(\mathrm{~s}, 6 \mathrm{H}, \mathrm{OCH}_{3}\right)$, $2.31\left(\mathrm{~m}, 2 \mathrm{H} ; \mathrm{C} \underline{\mathrm{H}}\left(\mathrm{CH}_{3}\right)_{2}\right), 1.89$ and $1.73\left(\mathrm{br}, 6 \mathrm{H}, \mathrm{CH}_{3} p-\right.$ cymene), $1.02 \mathrm{ppm}\left(\mathrm{br}, 12 \mathrm{H} ; \mathrm{CH}\left(\mathrm{C}_{3}\right)_{2}\right) ;{ }^{13} \mathrm{C} \mathrm{NMR}(100 \mathrm{MHz}$, $\left.\mathrm{CDCl}_{3}\right): \delta_{\mathrm{C}}=160.4(\mathrm{CO}), 133.8$ and $133.3(\mathrm{CH}$ thiol), 129.0 ( $\mathrm{CH}$ thiol), 114.9 ( $\mathrm{CH}$ thiol), 84.6-82.2 ( $\mathrm{Ar} \mathrm{CH} p$-cymene), $55.7\left(\mathrm{OCH}_{3}\right), 30.8\left(\underline{\mathrm{C}} \mathrm{H}\left(\mathrm{CH}_{3}\right)_{2}\right), 22.3\left(\mathrm{CH}\left(\mathrm{CH}_{3}\right)_{2}\right), 17.9 \mathrm{ppm}(p-$ cymene $\mathrm{CH}_{3}$ ); ESI-MS (positive mode, EtOH): $\mathrm{m} / \mathrm{z}$ 784.04; $\mathrm{Mw}=819.86 \mathrm{~g} / \mathrm{mol}$

\subsection{Reaction kinetics of 1-4 followed by ${ }^{1} \mathrm{H}$ NMR}

The kinetic of formation of complexes 1-4 was followed by NMR at $0{ }^{\circ} \mathrm{C}$ or $25^{\circ} \mathrm{C}$. For each reaction, $\left[\left(n^{6}-p-\right.\right.$ $\left.\left.\mathrm{MeC}_{6} \mathrm{H}_{4} \mathrm{Pr}^{i}\right) \mathrm{Ru}\left(\mu_{2}-\mathrm{Cl}\right) \mathrm{Cl}\right]_{2}$ was first dissolved in $500 \mu \mathrm{L} \mathrm{CD}_{2} \mathrm{Cl}_{2}$, and the NMR tube was sealed with a septum and flushed with stream of $\mathrm{N}_{2}$. Next, 4 eq of the corresponding thiophenol dissolved in $300 \mu \mathrm{L} \mathrm{CD}_{2} \mathrm{Cl}_{2}$ was injected into the tube (Table S9). Once prepared, each tube was immediately inserted into the spectrometer and NMR measurements were started at a spinning rate of $10 \mathrm{~Hz}$. For measurements at $0{ }^{\circ} \mathrm{C}$, the spectrometer was pre-cooled and ice-cold $\mathrm{CD}_{2} \mathrm{Cl}_{2}$ was used for sample preparation. Processed ${ }^{1} \mathrm{H} N \mathrm{NMR}$ spectra were transferred to Dynamic Center where normalised integrals of signals were 
plotted and fitted with built-in functions to find an optimal fit in order to obtain $k \cdot{ }^{69-71}$ The reaction in DCM at $45^{\circ} \mathrm{C}$ could not be performed directly in the tube. Instead, aliquots of each reaction mixture were collected at different time points, the original solvent immediately removed in vacuo, the residue dissolved in a suitable deuterated solvent and transferred into a new tube for NMR measurements. As such, only a low number of time points could be recorded, and $k$ values could not be calculated, but an estimation of the kinetic of the reaction was still possible at this temperature (Figures S34-39).

\section{Results and discussion}

\subsection{DFT calculations}

4.1.2 Formation mechanism The formation of dinuclear trithiolato-bridged arene ruthenium complexes is assumed to follow a three-step substitution mechanism (see Figure 2). In each of the first two steps, one of the bridging chlorine atoms is substituted by a thiolate ligand. The last step consists in accommodating the third bridging thiol, while releasing at the same time the remaining non-bridging chlorine atoms. Each of these steps is accompanied by the formation of one equivalent $\mathrm{HCl}$ while, additionally, in the last step, the complex acquires a singly positive charge with one chlorine ion providing counter charge. Each of the three individual steps consists of the release of the chlorine, the deprotonation of the thiol group and the insertion of the sulphur atom, the exact sequence of these sub steps as well as their respective contribution to the overall reaction barrier being unknown. Such detailed information on the formation mechanism would however be crucially required for a knowledge-based optimization of the synthesis conditions and the yield of such complexes. We hence determine the mechanism of each individual step by means of density functional theory (DFT) calculations on Complex 1.

We tested two pathways for the insertion of the first thiol. The first pathway proceeds by initially forming a Ru-S bond with the subsequent release of $\mathrm{HCl}$ and the second one by reversing these steps with initial $\mathrm{HCl}$ formation followed by insertion of the thiolate. We find both pathway initializations to converge to the same final mechanism with two transition states (see Figure S1a). The first lower-energy transition state corresponds to the Ru-S bond formation $(12.8 \mathrm{kcal} / \mathrm{mol})$, whereas the second higher-energy transition state is the thiol deprotonation (19.9 $\mathrm{kcal} / \mathrm{mol}$ ). In protic solvents thiols could exist as deprotonated anions and we would expect a reduced barrier for the second step. This is indeed confirmed by our calculations, where the barrier of insertion of the thiolate is reduced by $8.8 \mathrm{kcal} / \mathrm{mol}$ (see Figure S2). As these deprotonated systems are not charge neutral and computationally more challenging in our periodic setup, we will in the following consider only reaction mechanism for the neutral molecule but assume that protic solvents should systematically reduce reaction barriers.

The insertion of the second thiophenol follows the same mechanism as for the first one. However, the accommodation of the thiol in the Ru-complex core is hindered, which is reflected in the first transition state having a much higher activation barrier $(24.0 \mathrm{kcal} / \mathrm{mol}$, see Figure S1b). The deprotonation step on the other hand requires less energy $(10.9 \mathrm{kcal} / \mathrm{mol})$ than for the first insertion. The final step in the formation of the trithiolato Ru-complex is kinetically most demanding. While the barrier for the Ru-S bond formation is similar to the two preceding steps $(17.5 \mathrm{kcal} / \mathrm{mol})$, the deprotonation is accompanied by rearrangement of the two other thiol ligands, so as to accommodate the third one, which results in a barrier of $31.4 \mathrm{kcal} / \mathrm{mol}$ (see Figure S1c). The overall pathway for thiol ligands is shown as the black curve in Figure 3. It can be seen that the formation of all thiolato complexes is thermodynamically favourable. Nevertheless, the kinetic barriers continuously increase from formation of the monothiolato to the formation of the trithiolato complex, in correlation with lower experimental yield for the trithiolato complexes compared to mono- and dithiolato ones.

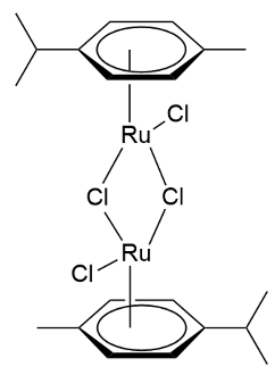

OS<smiles>[TeH2]C=[TeH2]</smiles>

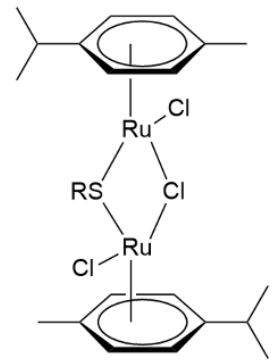

15

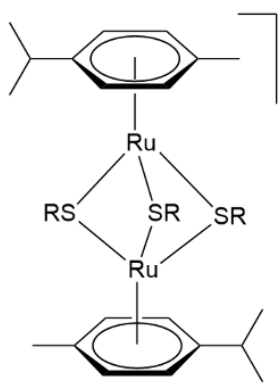

$3 S$

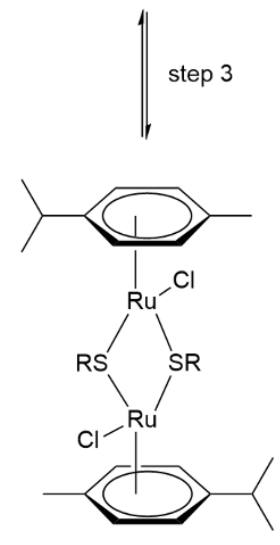

$2 S$
Figure 2. Stepwise formation of dinuclear trithiolato-bridged arene ruthenium complexes. We adopted the following abbreviations for the complexes - starting dimer $\left[\left(\eta^{6}-p-\mathrm{MeC}_{6} \mathrm{H}_{4} \mathrm{Pr}\right) \mathrm{Ru}\left(\mu_{2}-\mathrm{Cl}\right) \mathrm{Cl}\right]_{2} \quad: \quad \mathbf{O S}$, neutral monothiolato complex $\left[\left(\eta^{6}-p-\right.\right.$ $\left.\left.\mathrm{MeC}_{6} \mathrm{H}_{4} \mathrm{Pr}^{i}\right)_{2} \mathrm{Ru}_{2} \mathrm{Cl}_{2}(\mu-\mathrm{Cl})\left(\mu_{2}-\mathrm{SR}\right)\right]:$ 1S, neutral dithiolato complex $\left[\left(\eta^{6}-p-\right.\right.$ $\left.\left.\mathrm{MeC}_{6} \mathrm{H}_{4} \mathrm{Pr}^{2}\right)_{2} \mathrm{Ru}_{2}\left(\mu_{2}-\mathrm{SR}\right)_{2} \mathrm{Cl}_{2}\right]: \mathbf{2 S}$ and cationic trithiolato complex $\left[\left(\eta^{6}-p\right.\right.$ $\left.\left.\mathrm{MeC}_{6} \mathrm{H}_{4} \mathrm{Pr}^{i}\right)_{2} \mathrm{Ru}_{2}\left(\mu_{2}-\mathrm{SR}\right)_{3}\right]^{+}: \mathbf{3 S}$. 


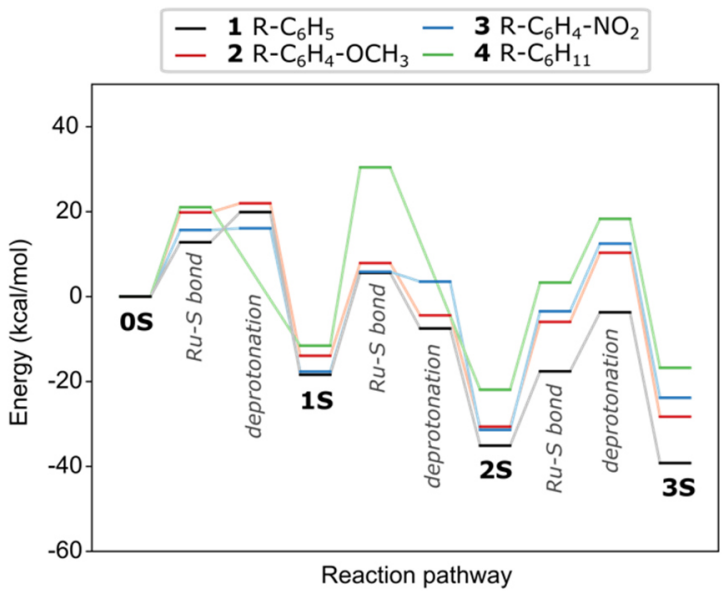

Figure 3. Energy evolution and transition states along the formation pathway form the starting dimer dichloride (0S) to the trithiolato (3S) Ru complex via the mono- (1S) and dithiolato complexes. The black line represents thiophenol, while the red, blue and green lines are for thiophenols with $-\mathrm{OCH}_{3}$ and $-\mathrm{NO}_{2}$ substituents in para position and cyclohexanethiol respectively. The values for the kinetic barriers are summarised in Table S1 (SI).

Electron withdrawing/donating substituents The reactivity of arene ligands can be tuned by the presence of different substituents on the benzene ring. For thiophenol, the presence of a strong electron withdrawing $-\mathrm{NO}_{2}$ group is expected to facilitate deprotonation. Indeed, we compute a deprotonation barrier that is $2.9 \mathrm{kcal} / \mathrm{mol}$ lower with the $-\mathrm{NO}_{2}$ group in para position (3) than without it (see Figure 3 and Figure S4). This kinetic enhancement is however not observed for the formation of the di- and trithiolato complex, where we predict almost no change in barrier and an increase by $10.4 \mathrm{kcal} / \mathrm{mol}$, respectively. In addition, the formation of the trithiolato complex is thermodynamically no longer favourable in presence of the $\mathrm{NO}_{2}$ group. The opposite effect in terms of deprotonation is expected for electron donating substituents, such as a methoxy group and indeed we systematically predict a slight increase in deprotonation activation energies with respect to the nonsubstituted ligands. Also, for the $-\mathrm{OCH}_{3}$ substituent (2) the formation of the trithiolato complex is kinetically strongly hindered and thermodynamically no longer favourable. In both cases the destabilization of the di- and trithiolato complexes as well as the increase in barriers leading to their formation can be ascribed on one hand to the increased steric bulkiness of the ligands, which negatively affects the overall cluster geometry. On the other hand, the destabilization can be attributed to the significant dipole moment each thiolato-ligand carries and introduces into the complex. In fact, both $-\mathrm{OCH}_{3}$ and $-\mathrm{NO}_{2}$ have non-negligible Hammett substituent constants $\sigma_{\mathrm{p}}$, 0.27 and $0.78^{72}$ respectively, which reflect the strong electron asymmetry within such thiols. The fact that $\mathbf{3 5}$ is destabilised disagrees with the experimental data, since the trithiolato $-\mathrm{NO}_{2}$ complex can be obtained in good yields (when performing the reaction in DCM as described in Experimental Section).

Aliphatic thiol We investigated the formation of the trithiolato complex in the case of the bulky aliphatic cyclohexanethiol (4), which was found difficult to obtain experimentally. ${ }^{48}$ Our simulations predict that the insertion of the ligand and the formation of the Ru-S bond is the only transition state for the first two steps (see Figure 3 and Figure S5), which points at steric hinderance. The energy necessary to insert the first cyclohexanethiol is similar to the other ligands, whereas the barrier of the second step is significantly higher, which could kinetically hinder the formation of the di- and trithiolato complexes. The final step, however, also has a transition state corresponding to the deprotonation step, in agreement with all other trithiolato-complexes. The kinetic barriers of this $\mathbf{2 S} \rightarrow \mathbf{3 S}$ step are still comparable to those for the substituted aromatic thiols.

Effect of the halogen in the starting dimer $\left[\left(\eta^{6}-p\right.\right.$ $\left.\mathrm{MeC}_{6} \mathrm{H}_{4} \mathrm{Pr}^{i}\right) \mathbf{R u}\left(\boldsymbol{\mu}_{2}-\mathrm{Cl}\right) \mathrm{Cl}_{2}$ Next, we investigate what effect the halogen has on the reaction by substituting chlorine with iodine in the starting dimer $\left[\left(\eta^{6}-p-\mathrm{MeC}_{6} \mathrm{H}_{4} \mathrm{Pr}^{i}\right) \mathrm{Ru}\left(\mu_{2}-1\right) I\right]_{2}$. In Figure 4 we compare the energy evolution of the three reaction steps and see that iodine increases (by $9.9 \mathrm{kcal} / \mathrm{mol}$ ) the barrier of the first step, changing it to the Ru-S bond formation instead of the deprotonation. The barriers for the subsequent steps remain roughly the same as for chlorine (see Table S2 for numerical values). We observe however a reduced thermodynamic stability in presence of iodine, the mono-, diand trithiolato complexes being significantly less stable than their chlorine counterparts and the formation of the trithiolato complex even being uphill in energy. As the structure of the trithiolato complex itself is the same for both halogens, this can be attributed to the weaker $\mathrm{H}-\mathrm{I}$ bond compared to $\mathrm{H}-\mathrm{Cl}$. While the kinetics are thus only mildly affected by iodine, we expect significantly less driving force for the formation of the thiolato complexes. Experimental results have indeed shown that trithiolato complexes $\left[\left(\eta^{6}-p-\mathrm{MeC}_{6} \mathrm{H}_{4} \mathrm{Pr}^{i}\right)_{2} \mathrm{Ru}_{2}\left(\mu_{2}-\mathrm{SC}_{6} \mathrm{H}_{4}-\mathrm{R}\right)_{3}\right]^{+}$ starting from $\left[\left(\eta^{6}-p-\mathrm{MeC}_{6} \mathrm{H}_{4} \mathrm{Pr}^{i}\right) \mathrm{Ru}\left(\mu_{2}-1\right) I\right]_{2}$ could not be obtained in pure form. ${ }^{73}$

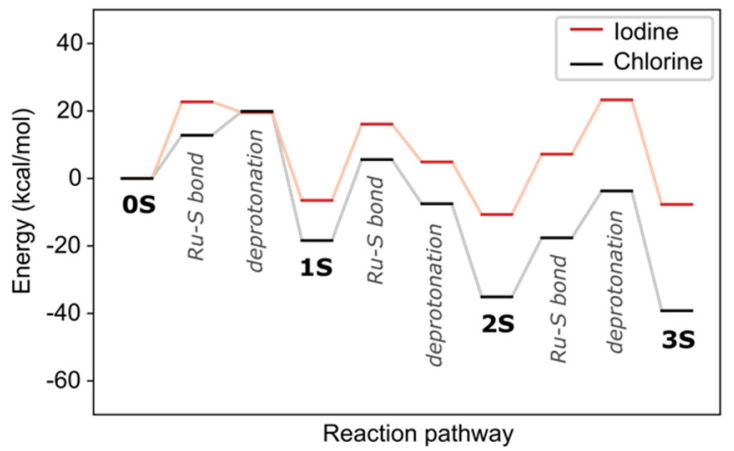

Figure 4. Energy evolution of the trithiolato complex 1 formation in presence of chlorine and iodine. The transition-state barriers are presented numerically in Table S2 (SI) and the NEB pathways can be found in Figure $\mathrm{S} 6$ (SI).

Temperature and solvent effects Based on the computed barriers, we estimate the reaction rates at $0{ }^{\circ} \mathrm{C}, 25^{\circ} \mathrm{C}, 45^{\circ} \mathrm{C}$ and $80^{\circ} \mathrm{C}$, where the last two temperatures correspond to the usual experimental conditions in dichloromethane (DCM) and ethanol 
respectively (see Section 2, Experimental results), using Eyring's equation ${ }^{74}$ within transition state theory the reaction rate is

$$
k=\frac{k_{B} T}{h} e^{-\frac{E^{\#}}{k_{B} T}}
$$

where $k_{B}$ is Boltzmann's constant, $T$ the temperature, $h$ Plank's constant, and $E^{\#}$ is the computed barrier, listed in Table S1. From the data shown in Figure 5 and Table S4, we can see that while steps 1 and 2 have reasonable reaction rates at room temperature, step 3 has very slow kinetics, which is further hindered by the substituents on the thiophenol. Only elevated temperatures lead to reaction rates that enable the complex formation on experimental timescales. These are in agreement with the experimental findings, that the $3^{\text {rd }}$ step needs significant thermal energy to proceed.

Experimentally, the three-step reaction takes place in a polar solvent, ethanol or DCM (in the present work). We simulate the polarizability of the solvent with an implicit solvation model, which correctly describes the electrostatic effect of medium. Accounting for any reaction with the solvent, however, such as $\mathrm{H}$-bonding or proton transfer would require computationally expensive molecular dynamics calculations, where the solute is simulated with explicit solvent molecules. A compromise could be the addition of a few solvent molecules in combination with implicit solvent. Considering though the great number of possible solvent orientations and interactions with structurally flexible solutes as shown by test calculations, in particular for the transition states, there is a considerable risk of missing important information and thus of compromising the validity of the results. We therefore consider that the implicit model, despite its limitations, yields more reliable trends for solvated complexes than a mixed explicit/implicit scheme. We perform calculations with dielectric constants 8.93 and 24.55, corresponding to DCM and ethanol respectively and show the energy evolution in Figure 6 and compare it with

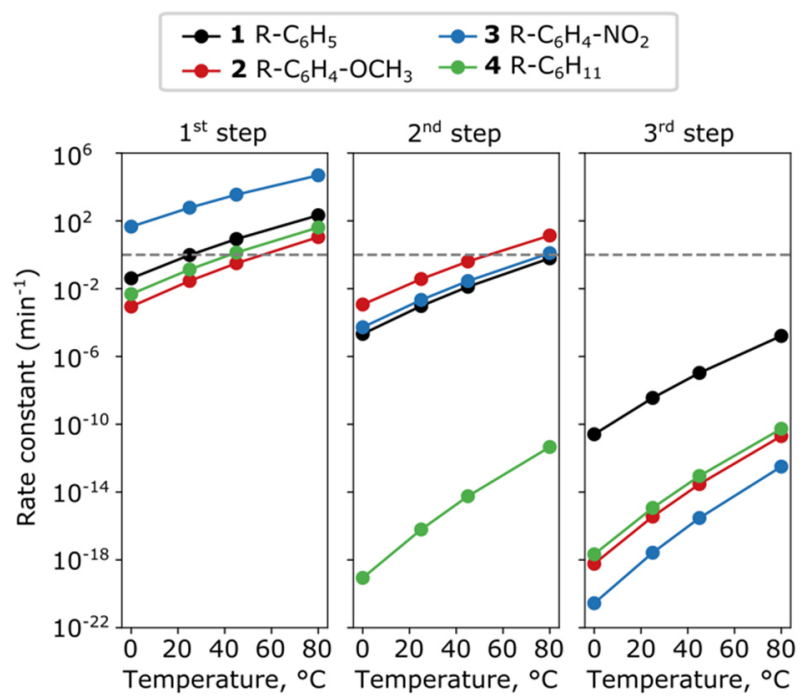

Figure 5. Change in the rate constants with temperature for the Complexes 1-4 for the three steps. The numerical values are summarised in Table S4 (SI).

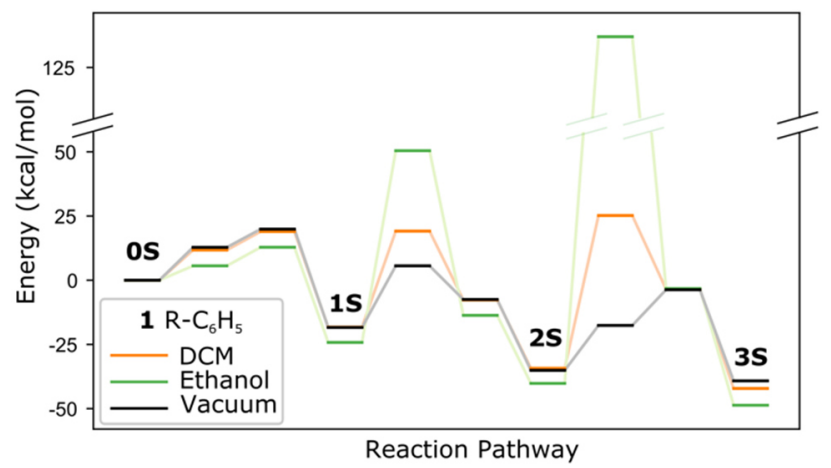

Figure 6. Effect of implicit DCM and ethanol solvents on the energy evolution. The numerical values are in Table S3 (SI).

the one in vacuum. The higher dielectric constant makes the thiolato complexes thermodynamically more favourable but has a distinct destabilizing effect on the transition states corresponding to the insertion of the thiol group into the complex' core. This increase of the barriers is less marked for the lower dielectric constant that however also does not stabilise the complexes as much. This suggests that strongly polar solvents are kinetically unfavourable for the formation of the di- and especially the trithiophenolato complexes.

The effect of the temperature on the reaction kinetics and the individual insertion of the thiol has already been experimentally demonstrated. For a given thiol, it was shown that the synthesis exclusively leads to the cationic trithiophenolato complex $\left[\left(\eta^{6}-p-\mathrm{MeC}_{6} \mathrm{H}_{4} \mathrm{Pr}^{i}\right)_{2} \mathrm{Ru}_{2}\left(\mu_{2}-\mathrm{SC}_{6} \mathrm{H}_{4}-\mathrm{R}\right)_{3}\right]^{+}$. At $0{ }^{\circ} \mathrm{C}$ and for thiols with decreased reactivity, typically benzylthiols, but also for some thiophenols, the neutral dithiophenolato complex $\left[\left(\eta^{6}-p-\mathrm{MeC}_{6} \mathrm{H}_{4} \mathrm{Pr}^{i}\right)_{2} \mathrm{Ru}_{2}\left(\mu_{2}-\mathrm{SC}_{6} \mathrm{H}_{4-}\right.\right.$ $\mathrm{R})_{2} \mathrm{Cl}_{2}$ ], or even the neutral monothiophenolato complex [ $\left(\eta^{6}-p\right.$ $\left.\left.\mathrm{MeC}_{6} \mathrm{H}_{4} \mathrm{Pr}^{i}\right)_{2} \mathrm{Ru}_{2} \mathrm{Cl}_{2}(\mu-\mathrm{Cl})\left(\mu_{2}-\mathrm{SC}_{6} \mathrm{H}_{4}-\mathrm{R}\right)\right]$ can be obtained in pure forms. ${ }^{49}$

\subsection{Experimental results}

Synthesis of complexes 1-3 The reaction pathway shown in Figure 6 suggests that a solvent with lower dielectric constant than the usual EtOH could kinetically favour the formation of the di- and especially trithiolato complexes. Trithiolato complexes should therefore be easier to obtain when the reaction is performed in DCM.

Complex 1 was obtained with a yield of $62 \%$ after a $7 \mathrm{~h}$ reaction performed at $45^{\circ} \mathrm{C}$ in DCM as compared to a $69 \%$ yield obtained from the same reaction but performed in EtOH at $80^{\circ} \mathrm{C}$ for $23 \mathrm{~h}$. In literature, $44 \%$ yield was reached for the reaction performed in $\mathrm{MeOH} .{ }^{34}$ More interestingly, irrespective of the solvent used, $\mathrm{EtOH}$ or DCM, the addition of DIPEA $1 \mathrm{~h}$ after beginning of the reaction allowed obtaining 1 in $80 \%$ or $79 \%$ yield, respectively, in only $3 \mathrm{~h}$. The reaction leading to 1 was followed by NMR spectroscopy (Figures 7-8; S34-35). It can be seen that at elevated temperatures, the dithiolato complex is readily formed followed by formation of the trithiolato complex. 
Interestingly, it seems that in $\mathrm{DCM}$ at $45^{\circ} \mathrm{C}$ the trithiolato complex is formed slightly faster compared to the reaction performed in $\mathrm{EtOH}$ at $80^{\circ} \mathrm{C}$. The reaction was also performed in $\mathrm{CD}_{2} \mathrm{Cl}_{2}$ at $25^{\circ} \mathrm{C}$ and $0{ }^{\circ} \mathrm{C}$ respectively, and followed by ${ }^{1} \mathrm{H} \mathrm{NMR}$, in order to determine experimental rate constants $k .{ }^{69-71}$ From the reactions performed at $0{ }^{\circ} \mathrm{C}$ and $25^{\circ} \mathrm{C}$, we were only able to estimate the rate constant for the dithiolato complex formation applying the Bodenstein approximation. ${ }^{75}$ The formation of the monothiolato complex is very fast and no reliable NMR data could be extracted. It turns out that the rate constant obtained from the kinetic data (see Table 1 and Figures S40, 41) was of the same order of magnitude as the one calculated for the reaction performed at $25^{\circ} \mathrm{C}$. Surprisingly and unlike theoretically predicted, the rate constant $k$ at $0^{\circ} \mathrm{C}$ is of similar order of magnitude.

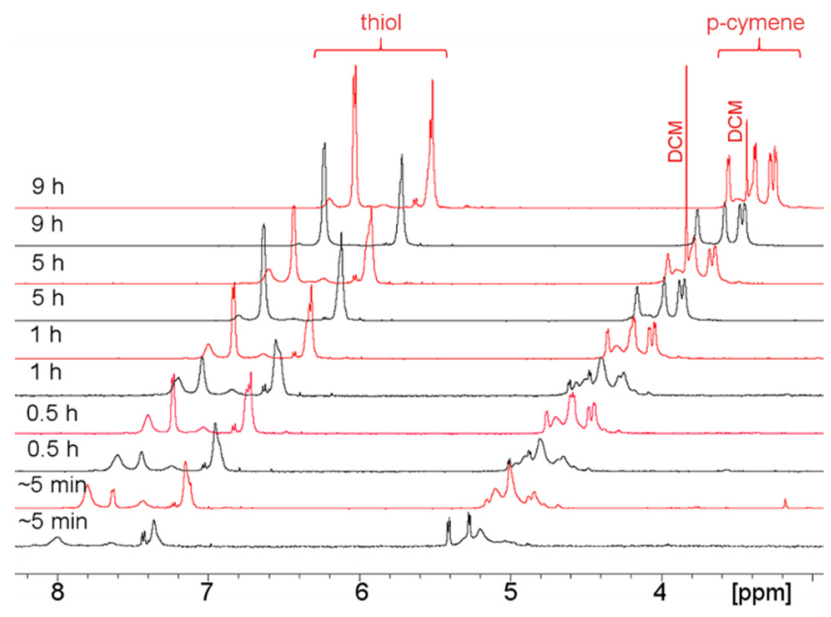

Figure 7. Synthesis of 1 followed by ${ }^{1} \mathrm{H}$ NMR. The spectra show the reaction monitoring (Thiol- (5-5.5 ppm) and p-cymene aromatic resonances (7-8 ppm) are shown) after $\sim 5 \mathrm{~min}, 0.5 \mathrm{~h}, 1 \mathrm{~h}, 5 \mathrm{~h}$, and $9 \mathrm{~h}$ ) in EtOH (black line) at $80^{\circ} \mathrm{C}$ and in DCM (red line) at $45^{\circ} \mathrm{C}$. Aliquots of reaction mixture samples at individual time points were dried and transferred to $\mathrm{CDCl}_{3}$ prior to measurement.

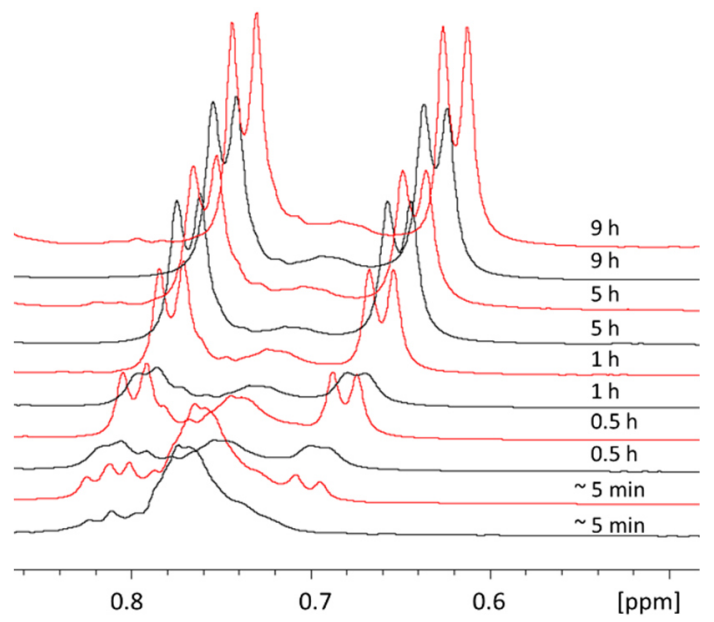

Figure 8. Synthesis of 1 followed by ${ }^{1} \mathrm{H}$ NMR. The spectra show the reaction monitoring (the $p$-cymene methyl resonances are shown) after $\sim 5 \mathrm{~min}, 0.5 \mathrm{~h}, 1 \mathrm{~h}, 5 \mathrm{~h}$, and $9 \mathrm{~h}$ ) in EtOH (black line) at $80^{\circ} \mathrm{C}$ and in DCM (red line) at $45^{\circ} \mathrm{C}$. Aliquots of reaction mixture samples at individual time points were dried and transferred to $\mathrm{CDCl}_{3}$ prior to measurement.

Complex 2 Complex 2 was obtained in 73\% yield from the reaction performed at $45^{\circ} \mathrm{C}$ in DCM after $9 \mathrm{~h}$ as compared to $93 \%$ yield obtained from $18 \mathrm{~h}$ reaction performed in $\mathrm{EtOH}$ at $80^{\circ} \mathrm{C} 76$. The rate constant $k$ of the corresponding dithiolato complex 8 obtained from the reaction in $\mathrm{CD}_{2} \mathrm{Cl}_{2}$ followed by ${ }^{1} \mathrm{H}$ NMR was close to the calculated $k$ (see Table 1 and Figure 9, S42, 43). Surprisingly and in contrast to calculations, $k$ obtained for the reaction performed at $25^{\circ} \mathrm{C}$ was lower than at $0{ }^{\circ} \mathrm{C}$. This could be ascribed to the different dependence of the forward and backward reaction rates with temperature (see Tables S4 and S5) if we assume the process to be in equilibrium. Indeed, the equilibrium constant $K$ at $0{ }^{\circ} \mathrm{C}$ is higher than the one at $25^{\circ} \mathrm{C}$ (see Table S6), so the forward reaction is favoured at lower temperatures. Interestingly, such a rate dependence was not observed for 1, even though, based on the calculations, we would expect even higher differences in $K$. This leads us to conclude that further processes and factors not captured by the calculations, i.e. solvents and entropy, ${ }^{77}$ are likely to play a role.

Table 1. Rate constants $k$ for the first two steps calculated from the constants of the individual steps (see Table S4) or determined experimentally from NMR kinetic data, respectively.

\begin{tabular}{ccccc}
\hline & \multicolumn{4}{c}{$\mathbf{k}_{\text {steps } \mathbf{1}+\mathbf{2}\left(\mathbf{m i n}^{-1}\right)}$} \\
\cline { 2 - 5 } $\mathrm{R}$ & \multicolumn{2}{c}{ Calculated } & \multicolumn{2}{c}{ Experimental } \\
\cline { 2 - 5 } & $\mathbf{0}{ }^{\circ} \mathbf{C}$ & $\mathbf{2 5}{ }^{\circ} \mathbf{C}$ & $\mathbf{0}^{\circ} \mathbf{C}$ & $\mathbf{2 5}{ }^{\circ} \mathbf{C}$ \\
\hline$-\mathrm{C}_{6} \mathrm{H}_{5}(\mathbf{1})$ & $8.6 \cdot 10^{-7}$ & $9.2 \cdot 10^{-2}$ & $7.5 \cdot 10^{-4}$ & $2.9 \cdot 10^{-3}$ \\
\hline$-\mathrm{C}_{6} \mathrm{H}_{4} \mathrm{OMe} \mathrm{(2)}$ & $1.1 \cdot 10^{-6}$ & $1.1 \cdot 10^{-3}$ & $6.5 \cdot 10^{-3}$ & $2.2 \cdot 10^{-3}$ \\
\hline$-\mathrm{C}_{6} \mathrm{H}_{4} \mathrm{NO}_{2}(\mathbf{3})$ & $2.4 \cdot 10^{-3}$ & 1.32 & $9.2 \cdot 10^{-3}$ & $1.2 \cdot 10^{-3}$ \\
\hline
\end{tabular}

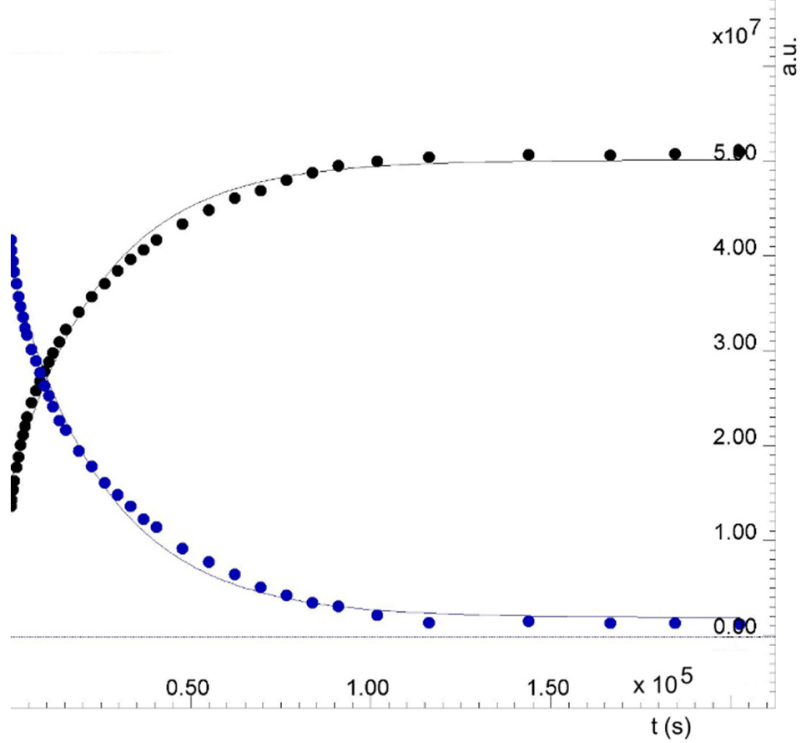

Figure 9. Formation of 2. Reaction between the dimer $\left[\left(\eta_{6}-p-M_{e} C_{6} \mathrm{H}_{4} \mathrm{Pr}\right) \mathrm{Ru}\left(\mu_{2}-\mathrm{Cl}\right) \mathrm{Cl}\right]_{2}$ and p-methoxythiophenol in $\mathrm{CD}_{2} \mathrm{Cl}_{2}$ at $25^{\circ} \mathrm{C}$ followed by ${ }^{1} \mathrm{H}$ NMR. The data points represent normalised integrals. Black: resonance at $6.86 \mathrm{ppm}$ ( $p$-methoxythiophenol, 2) blue: resonance at $5.34 \mathrm{ppm}$ ( $p$-cymene ring, starting dimer). 
Complex 3 Complex 3 was obtained with a yield of $73 \%$ of when the reaction was performed in DCM at $45{ }^{\circ} \mathrm{C}$ compared to $48 \%$ reported in literature for the reaction performed in $\mathrm{EtOH}$ under reflux for $18 \mathrm{~h} .{ }^{19}$ The reaction in $\mathrm{CD}_{2} \mathrm{Cl}_{2}$ was followed at $0{ }^{\circ} \mathrm{C}$ and $25^{\circ} \mathrm{C}$. The rate constant obtained for the corresponding dithiolato complex was of the same order of magnitude as the one calculated for the reaction performed at $0{ }^{\circ} \mathrm{C}$ (Table 1 ; Figure S15-16). Similarly to 2 , the reaction appears to be faster at $0{ }^{\circ} \mathrm{C}$ as opposed to $25^{\circ} \mathrm{C}$. At $45{ }^{\circ} \mathrm{C}$, the results suggest that $p$ nitrothiophenol reacts immediately with the dimer $\left[\left(n_{6}-p\right.\right.$ $\mathrm{MeC}_{6} \mathrm{H}_{4} \mathrm{Pr}$ ) Ru( $\left.\left.\mu_{2}-\mathrm{Cl}\right) \mathrm{Cl}\right]_{2}$ (Figure $\mathrm{S} 44,45$ ).

Synthesis of the new trithiolato complexes 4 and 5 The synthesis of $\mathbf{4}$ was attempted several years ago by Süss-Fink and coworkers, but they could only obtain the neutral dithiolato complex $\left[\left(\eta^{6}-p-\mathrm{MeC}_{6} \mathrm{H}_{4} \mathrm{Pr}^{i}\right)_{2} \mathrm{Ru}_{2}\left(\mu_{2}-\mathrm{SC}_{6} \mathrm{H}_{11}\right)_{2} \mathrm{Cl}_{2}\right]$, which did not react further in ethanol heated at reflux, presumably due to steric reasons. ${ }^{48}$ Indeed, computational results predict high barriers already for the mono- and dithiolato intermediates. The difficulty to obtain $\mathbf{4}$ is in this context not surprising. Nevertheless, by significantly extending the reaction time, performing the reaction in DCM and using activating DIPEA, we were able to obtain 4 , however not in a pure form, as inseparable mixtures containing the dithiolato complex $\left[\left(\eta^{6}-p\right.\right.$ $\left.\mathrm{MeC}_{6} \mathrm{H}_{4} \mathrm{Pr}^{i}\right)_{2} \mathrm{Ru}_{2}\left(\mu_{2}-\mathrm{SC}_{6} \mathrm{H}_{11}\right)_{2} \mathrm{Cl}_{2}$ ] (and possibly other impurities) were always obtained. Determining $k$ by ${ }^{1} \mathrm{H}$ NMR for the reaction of cyclohexylthiol with the starting dimer in $\mathrm{CD}_{2} \mathrm{Cl}_{2}$ was not successful in this case. The results however show that the reaction proceeds rather slowly (Figure S46, 47).

The new complex $\mathbf{5}$ with aliphatic thiol ligands has been obtained in $62 \%$ yield from the reaction in DCM with addition of DIPEA. An analogous reaction in ethanol with addition of DIPEA lead to $42 \%$ yield. Attempts to obtain 5 by performing the reaction in DCM without DIPEA were unsuccessful, only the neutral dithiolato complex $\left[\left(\eta^{6}-p-\mathrm{MeC}_{6} \mathrm{H}_{4} \mathrm{Pr}^{i}\right)_{2} \mathrm{Ru}_{2}\left(\mu_{2^{-}}\right.\right.$ $\left.\mathrm{SC}_{6} \mathrm{H}_{13}\right)_{2} \mathrm{Cl}_{2}$ ] was observed, which can be ascribed to the low reactivity of 1-hexanethiol. Of note, a similar trithiolato complex $\left[\left(\eta^{6}-p-\mathrm{MeC}_{6} \mathrm{H}_{4} \mathrm{Pr}^{i}\right)_{2} \mathrm{Ru}_{2}\left(\mu_{2}-\mathrm{SC}_{8} \mathrm{H}_{17}\right)_{3}\right]^{+}$was obtained by Stibal et al. in 2016, who reported an analogous reaction with octanethiol under reflux in $\mathrm{EtOH}$ for $168 \mathrm{~h}$ and obtained $28 \%$ yield. ${ }^{50}$

Synthesis of the trithiolato complex 6 In the literature, 6 was obtained in $45 \%$ yield from the reaction between the starting dimer and $p$-fluorothiophenol in refluxing ethanol for $18 \mathrm{~h} .{ }^{76} \mathrm{By}$ performing the reaction in DCM and adding DIPEA after $2 \mathrm{~h}$, we were able to obtain 6 in $80 \%$ yield in only $3.5 \mathrm{~h}$.

Synthesis of the new dithiophenolato complexes 7 and 8 So far, only dithiobenzylato complexes were reported, but no dithiophenolato. Thiophenols were considered to be too reactive, and the reactions with the starting dimer always led to inseparable mixtures of trithiolato and dithiolato complexes. ${ }^{47}$ By using optimised conditions, we were able to obtain the two new dithiophenolato complexes $\mathbf{7}$ and $\mathbf{8}$ from the reaction in DCM at $0{ }^{\circ} \mathrm{C}$. Notably, 7 was obtained in quantitative yield and good purity. While $\mathbf{8}$ could not be purified to a satisfactory degree, we can confirm that $\mathbf{8}$ was indeed formed. A further reaction using these two new intermediates with another thiol could thus lead to new mixed trithiolato complexes of the form $\left[\left(\eta^{6}-p-\mathrm{MeC}_{6} \mathrm{H}_{4} \mathrm{Pr}^{i}\right)_{2} \mathrm{Ru}_{2}\left(\mu_{2}-\mathrm{SC}_{6} \mathrm{H}_{4}-p-\mathrm{Bu}^{t}\right)_{2}\left(\mu_{2}-\mathrm{R}\right)\right]^{+}$and $\left[\left(\eta^{6}-p-\right.\right.$
$\left.\left.\mathrm{MeC}_{6} \mathrm{H}_{4} \mathrm{Pr}^{i}\right)_{2} \mathrm{Ru}_{2}\left(\mu_{2}-\mathrm{SC}_{6} \mathrm{H}_{4}-p-\mathrm{OMe}\right)_{2}\left(\mu_{2}-\mathrm{R}\right)\right]^{+}$, which could have interesting anticancer and antiparasitic properties.

\section{Conclusions}

In summary, we have conducted a DFT study aiming at a fundamental understanding of the reaction mechanisms leading to the formation of dinuclear thiolato-bridged arene ruthenium complexes $\left[\left(\eta^{6}-p-\mathrm{MeC}_{6} \mathrm{H}_{4} \mathrm{Pr}^{i}\right)_{2} \mathrm{Ru}_{2}\left(\mu_{2}-\mathrm{SC}_{6} \mathrm{H}_{4}-\mathrm{R}\right)_{3}\right]^{+}$ starting from the dichloro(p-cymene)ruthenium(II) dimer $\left[\left(n^{6}-\right.\right.$ $\left.\left.p-\mathrm{MeC}_{6} \mathrm{H}_{4} \mathrm{Pr} i\right) \mathrm{Ru}\left(\mu_{2}-\mathrm{Cl}\right) \mathrm{Cl}\right]_{2}$. Further, we studied variations in reaction conditions experimentally and followed the kinetics with NMR.

The presence of electron-withdrawing or donating substituents on the thiol significantly influences the formation of the trithiolato complex, which is thermodynamically no longer favourable in presence of the former. In addition, the calculated reaction pathways suggest using a solvent with a lower dielectric constant could decrease the kinetic barriers for the formation of the di- and trithiolato complexes. Experimentally, changing the reaction solvent from EtOH to DCM indeed leads mostly to similar or better yields, but at lower temperature as compared to EtOH. Use of a base such as DIPEA allows to further increase the yield in a shorter reaction time. By this tuning of the reaction conditions, we were able to synthesise two new trithiolato complexes with aliphatic thiol ligands, improve the yields for two trithiolato complexes with aromatic thiol ligands and further synthesise two new dithiophenolato complexes, impossible to obtain so far. As such, our results and suggested adapted synthetic route open new possibilities for the synthesis of so far inaccessible dinuclear dithiophenolato- and especially trithiolato-bridged arene ruthenium(II) complexes that are known to possess very interesting anticancer and antiparasitic properties. More generally, the synthesis of other challenging thiolato-bridged dinuclear group 8 and 9 metal complexes could be reexamined.

\section{Conflicts of interest}

There are no conflicts to declare.

\section{Acknowledgements}

This research was funded by the SNF Professorship Grant PPOOP2_157615. Calculations were performed on UBELIX (http://www.id.unibe.ch/hpc), the HPC cluster at the University of Bern

\section{References}

1 S. C. and J. Q. Yanhui Chen, Ying Peng, Pingping Chen, Jinfeng Zhao, Litao Liu, Yang Li, Dalt. Trans., 2010, 39, 3020-3025.

2 Y. Chen, Y. Zhou, P. Chen, Y. Tao, Y. Li, J. Qu, R. Me, R. Ph and R. Et, J. Am. Chem. Soc., 2008, 2, 15250-15251.

3 Y. Chen, Y. Zhou and J. Qu, Organometallics, 2008, 27, 666671. 
4 J. Zhao, L. Wang, Y. Zhou, Y. Zhang, N. Zhang, C. Jia, F. Hu, Y. Chen, B. Wang and J. Qu, Inorg. Chem. Commun., 2013, 29, 179182.

5 G. Gupta, N. Nagesh, B. S. Murray, P. J. Dyson and B. Therrien, Inorganica Chim. Acta, 2014, 423, 31-35.

6 J. Boudreau, J. Grenier-Desbiens and F.-G. Fontaine, Eur. J. Inorg. Chem., 2010, 2010, 2158-2164.

7 F. Takagi, H. Seino, M. Hidai and Y. Mizobe, Organometallics, 2003, 22, 1065-1071.

8 M. H. Fusao Takagi, Hidetake Seino, Yasushi Mizobe, Can. J. Chem., 2001, 79, 632-634.

9 F. Takagi, H. Seino, Y. Mizobe and M. Hidai, Organometallics, 2002, 21, 694-699.

10 G. Gupta, A. Garci, B. S. Murray, P. J. Dyson, G. Fabre, P. Trouillas, F. Giannini, J. Furrer, G. Süss-Fink and B. Therrien, Dalt. Trans., 2013, 42, 15457-15463.

11 J. P. Johnpeter, G. Gupta, J. M. Kumar, G. Srinivas, N. Nagesh and B. Therrien, Inorg. Chem., 2013, 52, 13663-13673.

12 G. Gupta, B. S. Murray, P. J. Dyson and B. Therrien, J. Organomet. Chem., 2014, 767, 78-82.

13 M. Gras, B. Therrien, G. Süss-Fink, O. Zava and P. J. Dyson, Dalt. Trans., 2010, 39, 10305-10313.

14 G. Süss-Fink, Dalt. Trans., 2010, 39, 1673-1688.

15 J. Furrer and G. Süss-Fink, Coord. Chem. Rev., 2016, 309, 3650.

16 A. P. Basto, J. Müller, R. Rubbiani, D. Stibal, F. Giannini, G. Süss-Fink, V. Balmer, A. Hemphill, G. Gasser and J. Furrer, Antimicrob. Agents Chemother., 2017, 61, e01031-17.

17 A. P. Basto, N. Anghel, R. Rubbiani, J. Müller, D. Stibal, F. Giannini, G. Süss-Fink, V. Balmer, G. Gasser, J. Furrer and A Hemphill, Metallomics, 2019, 11, 462-474.

18 F. Giannini, G. Süss-Fink and J. Furrer, Inorg. Chem., 2011, 50 , 10552-10554.

19 F. Giannini, J. Furrer, A. F. Ibao, G. Süss-Fink, B. Therrien, O. Zava, M. Baquie, P. J. Dyson and P. Štěpnička, J. Biol. Inorg. Chem., 2012, 17, 951-960.

20 J. F. F. Giannini, L. E. H. Paul, Chimia (Aarau)., 2012, 66, 775780.

21 F. Giannini, J. Furrer, G. Süss-Fink, C. M. Clavel and P. J. Dyson, J. Organomet. Chem., 2013, 744, 41-48.

22 F. Giannini, L. E. H. Paul, J. Furrer, B. Therrien and G. Süss-Fink, New J. Chem., 2013, 37, 3503-3511.

23 F. Giannini, M. Bartoloni, L. E. H. Paul, G. Süss-Fink, J. L. Reymond and J. Furrer, Medchemcomm, 2015, 6, 347-350.

24 F. Giannini, L. Geiser, L. E. H. Paul, T. Roder, B. Therrien, G. Süss-Fink and J. Furrer, J. Organomet. Chem., 2015, 783, 40-45.

25 P. Tomšík, D. Muthná, M. Řezáčová, S. Mičuda, J. Ćmielová, M. Hroch, R. Endlicher, Z. Červinková, E. Rudolf, S. Hann, D. Stíbal, B. Therrien and G. Süss-Fink, J. Organomet. Chem., 2015, 782, 4251.

26 M. B. Gomes de Lima, J. E. Guerchais, F. Y. Pétillon and R. Mercier, Organometallics, 1986, 5, 1952-1964.

27 F. Y. Pétillon, P. Schollhammer, J. Talarmin and K. W. Muir Coord. Chem. Rev., 1998, 178-180, 203-247.

28 F. Y. Pétillon, P. Schollhammer and J. Talarmin, Coord. Chem. Rev., 2017, 331, 73-92.

29 H. S. G. Winkhaus, J. Organomet. Chem., 1967, 7, 487-491.

30 R. A. Zelonka and M. C. Baird, J. Organomet. Chem., 1972, 44, 383-389.

31 R. A. Zelonka and M. C. Baird, J. Organomet. Chem., 1972, 35, C43-C46.

32 R. A. Zelonka and M. C. Baird, Can. J. Chem., 1972, 50, 30633072.

33 H. T. Schacht, R. C. Haltiwanger and M. R. DuBois, Inorg. Chem., 1992, 31, 1728-1730.

34 K. Mashima, A. Mikami and A. Nakamura, Chem. Lett., 1992, 21, 1795-1798.
35 P. J. Dyson, G. Süss-Fink, F. Giannini, J. Furrer and C. M. Clavel, J. Organomet. Chem., 2013, 744, 41-48.

36 D. Stíbal, L. Geiser, G. Süss-Fink and J. Furrer, RSC Adv., 2016, 6, 38332-38341.

37 F. Chérioux, C. M. Thomas, T. Monnier and G. Süss-Fink, Polyhedron, 2003, 22, 543-548.

38 F. Chérioux, B. Therrien and G. Süss-Fink, Inorganica Chim. Acta, 2004, 357, 834-838.

39 G. Süss-Fink and B. Therrien, Organometallics, 2007, 26, 766774.

40 F. Chérioux, C. M. Thomas, B. Therrien and G. Süss-Fink, Chem. - A Eur. J., 2002, 8, 4377-4382.

41 C. G. Hartinger, M. A. Jakupec, S. Zorbas-Seifried, M. Groessl, A. Egger, W. Berger, H. Zorbas, P. J. Dyson and B. K. Keppler, Chem. Biodivers., 2008, 5, 2140-2155.

42 E. S. Antonarakis and A. Emadi, Cancer Chemother. Pharmacol., 2010, 66, 1-9.

43 G. Gasser, I. Ott and N. Metzler-Nolte, J. Med. Chem., 2011, 54, 3-25.

44 D. Muthná, P. Tomšík, R. Havelek, R. Köhlerová, V. Kasilingam, E. Čermáková, D. Stíbal, M. Řezáčová and G. Süss-Fink, Anticancer. Drugs, 2016, 27, 643-650.

45 H. Primasová, L. E. H. Paul, G. Diserens, E. Primasová, P. Vermathen, M. Vermathen and J. Furrer, Metabolites, 2019, 9, 146.

46 D. Stíbal, B. Therrien, G. Süss-Fink, P. Nowak-Sliwinska, P. J. Dyson, E. Čermáková, M. Řezáčová and P. Tomšík, J. Biol. Inorg. Chem., 2016, 21, 443-452.

47 J. Jelk, V. Balmer, D. Stibal, F. Giannini, G. Süss-Fink, P. Bütikofer, J. Furrer and A. Hemphill, Exp. Parasitol., 2019, 205, 107753.

48 A.-F. Ibao, M. Gras, B. Therrien, G. Suess-Fink, O. Zava and P. J. Dyson, Eur. J. Inorg. Chem., 2012, 2, 1531-1535.

49 D. Stíbal, B. Therrien, F. Giannini, L. E. H. Paul, J. Furrer and G. Süss-Fink, Eur. J. Inorg. Chem., 2014, 2014, 5925-5931.

50 D. Stíbal, T. Riedel, P. J. Dyson, G. Süss-Fink and B. Therrien, Inorganica Chim. Acta, 2016, 444, 51-55.

$51 \mathrm{~J}$. Hutter, M. Iannuzzi, F. Schiffmann and J. Vandevondele, Wiley Interdiscip. Rev. Comput. Mol. Sci., 2014, 4, 15-25.

52 G. Lippert, J. Hutter and M. Parrinello, Mol. Phys., 1997, 92, 477-488.

53 J. Vandevondele, M. Krack, F. Mohamed, M. Parrinello, T. Chassaing and J. Hutter, Comput. Phys. Commun., 2005, 167, 103128.

54 S. Goedecker, M. Teter and J. Hutter, Phys. Rev. B, 1996, 54, 1703.

55 M. Krack, Theor. Chem. Acc., 2005, 114, 145-152.

$56 \mathrm{~J}$. VandeVondele and J. Hutter, J. Chem. Phys., 2007, 127, 114105.

57 A. D. Becke, Phys. Rev. A, 1988, 4, 276-282.

58 C. Lee, W. Yang and R. G. Parr, Phys. Rev. B, 1988, 37, 785789.

59 S. Grimme, J. Antony, S. Ehrlich and H. Krieg, J. Chem. Phys., 2010, 132, 154104

60 S. Grimme, S. Ehrlich and L. Goerigk, J. Comput. Chem., 2011, 32, 1456-1465.

61 T. Zábojníková, R. Cajzl, J. Kljun, Z. Chval, I. Turel and J. V. Burda, J. Comput. Chem., 2016, 37, 1766-1780.

62 I. Czerwinska, J. Far, C. Kune, C. Larriba-Andaluz, L. Delaude and E. De Pauw, Dalt. Trans., 2016, 45, 6361-6370.

63 G. Gupta, A. Garci, B. S. Murray, P. J. Dyson, G. Fabre, P. Trouillas, F. Giannini, J. Furrer, G. Süss-Fink and B. Therrien, Dalt. Trans., 2013, 42, 15457.

64 I. del Rosal, T. Gutmann, L. Maron, F. Jolibois, B. Chaudret, B. Walaszek, H.-H. Limbach, R. Poteau and G. Buntkowsky, Phys. Chem. Chem. Phys., 2009, 11, 5657.

65 J. VandeVondele and J. Hutter, J. Chem. Phys., 2003, 118, 4365-4369. 
66 G. Henkelman, B. P. Uberuaga, H. Jónsson and G. Henkelman, J. Chem. Phys., 2011, 9901, 1-5.

67 O. Andreussi, I. Dabo and N. Marzari, J. Chem. Phys., 2012, 136, 064102.

68 J. Riddick and W. Bunger, Organic Solvents: Physical Properties and Methods of Purification, Band 2, Wiley-Interscience, 3rd ed. 1970.

69 Dynamics Center 2.5.6 https://www.bruker.com/products/mr/nmr/software/dynamicscenter.html, (accessed 29 November 2019).

70 H. Akaike, IEICE Trans. Fundam. Electron. Commun. Comput. Sci., 1974, 19, 716-723.

71 F. Susanne, D. S. Smith and A. Codina, Org. Process Res. Dev., 2012, 16, 61-64.

72 C. Hansch, A. Leo and R. W. Taft, Chem. Rev., 1991, 91, 165195.

73 L. Geiser, University of Bern, 2015.

74 H. Eyring, The Activated Complex in Chemical Reactions, 1935, vol. 3.

75 F. G. Helfferich, Kinetics of Multistep Reactions, Elsevier, 2004. 76 F. Giannini, J. Furrer, A. F. Ibao, G. Süss-Fink, B. Therrien, O. Zava, M. Baquie, P. J. Dyson and P. Štěpnička, J. Biol. Inorg. Chem., 2012, 17, 951-960.

77 L. E. Revell and B. E. Williamson, J. Chem. Educ., 2013, 90, 1024-1027. 